\title{
An atypical presentation of giant cell arteritis
}

\author{
Jocelyn Zwicker MD, Edward J. Atkins MD, Cheemun Lum MD, Mukul Sharma MD
}

See related practice article by Belliveau and ten Hove, available at www.cmaj.ca

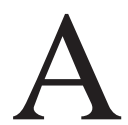
n 85-year-old man presented to the emergency department with difficulty walking, dizziness and double vision that had lasted for one week. He had previously experienced several weeks of temporal headache and weight loss. Abnormal findings on neurologic examination included upbeat nystagmus, gaze palsy when looking to the right and gait ataxia.

Diffusion-weighted magnetic resonance imaging (MRI) showed multiple, small, acute and subacute infarcts in the pons, cerebellar hemispheres and occipital lobes. A computed tomography (CT) angiogram showed bilateral concentric thickening of the walls of the vertebral arteries extracranially (Figure 1) with irregular, concentric stenoses of these arteries from the subclavian artery to the upper cervical vertebrae. The radiologic differential diagnosis included bilateral dissection of the vertebral arteries, but it did not include giant cell arteritis. Our patient was given treatment with intravenous heparin, followed by warfarin for the presumed dissection. After four weeks in hospital, he was discharged to a stroke rehabilitation facility.

Six weeks after being discharged from hospital, the patient was readmitted with a decreased level of consciousness, dysarthria and worsening ataxia. A diffusion-weighted MRI showed new infarcts in the pons, cerebellum and midbrain. A magnetic resonance angiogram showed severely diminished blood flow in his basilar artery, as well as extensive multifocal areas of diminished flow within the vertebral arteries. A new, moderately severe, area of stenosis within the petrous portion of his left internal carotid artery was evident (Figure 2).

The rapid progression of changes in the large vessels led to the consideration of vasculitis as a possible diagnosis. Our patient's erythrocyte sedimentation rate was $30 \mathrm{~mm} / \mathrm{h}$ (the upper limit of normal varies between laboratories, but it is $6 \mathrm{~mm} / \mathrm{h}$ at our institution) and his C-reactive pro- tein level was 25 (normal < 8) mg/L. When adjusted for age, the erythrocyte sedimentation rate could be interpreted as normal (upper limit of normal of the the age-adjusted rate for men is calculated as age in years $\div 2$; for women, it is calculated as [age in years +10$] \div 2$ ). ${ }^{1}$ His hemoglobin level was normal, and laboratory markers of systemic vasculitis were negative.

Given the initial involvement of large, extracranial arteries, our patient's advanced age and his continued weight loss, giant cell arteritis rather than primary central nervous system angiitis became our working diagnosis. Treatment
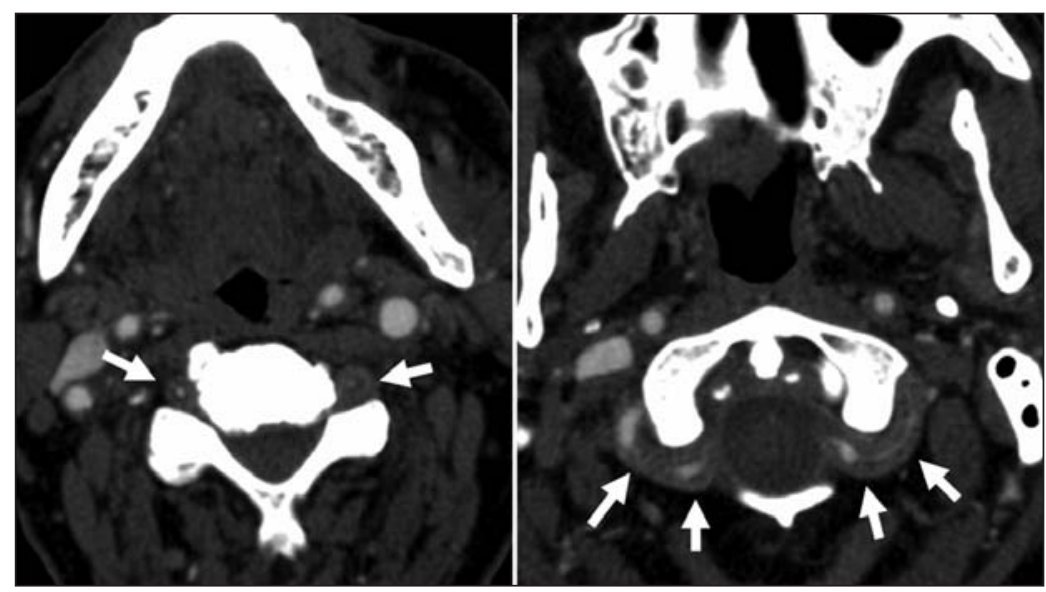

Figure 1: Axial computed tomography angiograms of an 85-year-old man with ataxia, vertigo and diplopia. Note the bilateral concentric thickening of the vertebral arteries (white arrows).

\section{- Ker POINTS}

- Given the wide spectrum of presentations of giant cell arteritis, physicians need to be equally familiar with both typical and atypical presentations.

- The presenting manifestation of giant cell arteritis may be stroke. Giant cell arteritis should be considered as a cause of stroke in patients with "red flags."

- Concentric, long-segment, increased thickening of the arterial wall, particularly extracranially, on computed tomography angiography may indicate giant cell arteritis. 


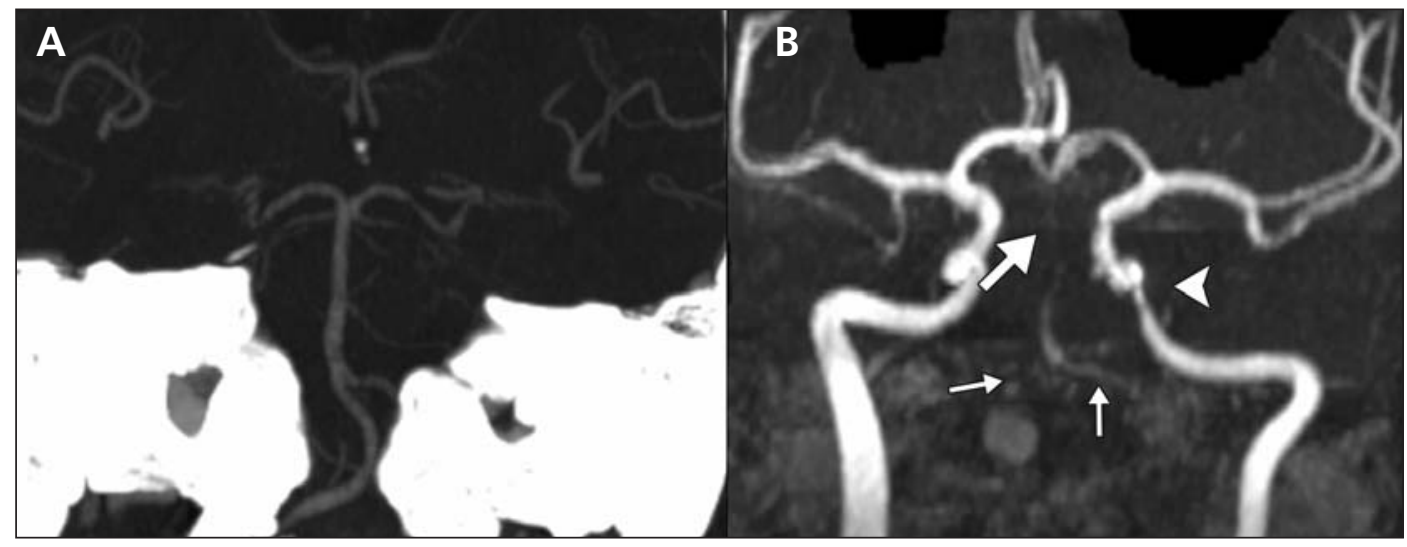

Figure 2: (A) Computed tomography angiogram showing a patent basilar artery. (B) A magnetic resonance angiogram taken 10 weeks later showing severe stenosis of the vertebral arteries (small arrows), severely diminished flow in the basilar artery (large arrow) and new stenosis in the petrous portion of the left carotid artery (arrowhead).

with methylprednisolone $(1 \mathrm{~g} / \mathrm{d}$ intravenously) was initiated empirically. Cerebral angiography performed within 24 hours of the start of treatment showed occlusions of the vertebral arteries bilaterally and filling of the basilar artery coming only from collateral vessels. Irregular beading and stenoses were seen in the superficial temporal arteries, which is consistent with giant cell arteritis. A biopsy of the superficial temporal arteries 48 hours after the start of steroid therapy showed the classic pattern of granulomatous inflammation indicative of giant cell arteritis (Figure 3). Our patient's level of consciousness continued to deteriorate and, despite aggressive therapy with high doses of steroids given intravenously, he died of respiratory arrest the fol-

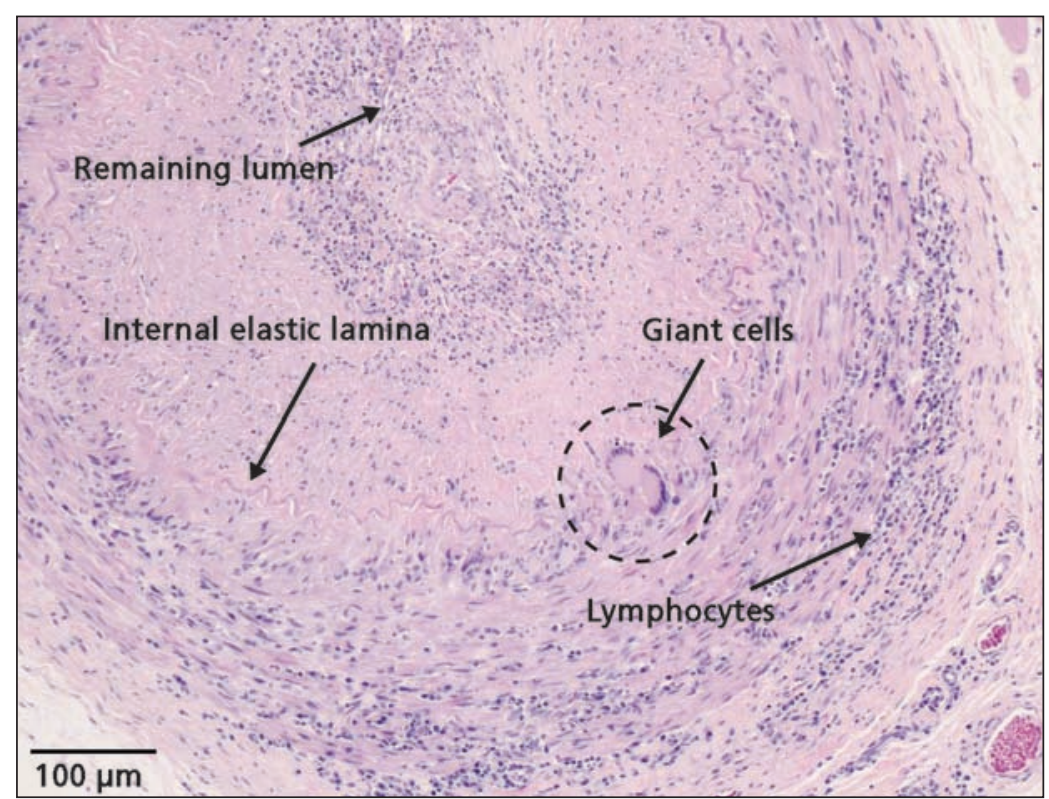

Figure 3: Biopsy specimen of the left temporal artery showing multinucleated giant cells, fragmentation of the internal elastic lamina and lymphocytic infiltrate consistent with giant cell arteritis. The slide was stained with hematoxylin and eosin. lowing day. The respiratory arrest was presumed to be secondary to brainstem ischemia. His family declined an autopsy.

\section{Discussion}

The diagnosis of giant cell arteritis (also known as temporal arteritis) was not initially considered in our patient because it was not a classic presentation. Classic features of giant cell arteritis include headache, claudication of the jaw and tongue, loss of vision in one eye, fever, myalgia, weight loss, anorexia and fatigue (Table 1)..$^{2-4}$ Diagnostic criteria established by the American College of Rheumatology (Box 1) ) $^{5}$ reportedly have a sensitivity of $93.5 \%$ and a specificity of $91.2 \%$; however, as many as $40 \%$ of presentations may be atypical. ${ }^{4}$

Fifteen per cent of patients may present with fever alone. ${ }^{3}$ Although loss of vision due to ischemic optic neuritis is a well-known complication of giant cell arteritis, $21.2 \%$ of patients with giant cell arteritis and visual symptoms have no other cranial or systemic manifestations. $^{2}$ Arteritis may involve the aorta and its main branches, so patients may present with chest pain that radiates to the interscapular area or symptoms related to reduced blood flow in the upper extremites. ${ }^{3}$ Giant cell arteritis presenting as severe anemia, scalp necrosis, pericardial and pleural effusion, dry cough, toothache, intermittent diplopia, peripheral nerve symptoms, female genital tract involvement or stroke has also been reported. ${ }^{3}$

Our patient presented with symptoms of posterior circulation stroke (Box 2). Giant cell arteritis is often overlooked as a possible cause of stroke, because it is reportedly the cause of firstever stroke in only $0.11 \%$ of patients. ${ }^{6}$ Because the diagnosis of giant cell arteritis was not ini- 
tially considered in our patient, we missed the significance of his weight loss and headache, and an erythrocyte sedimentation rate was not initially ordered.

\section{Investigations}

Giant cell arteritis is a neurologic emergency, and urgent investigation is required. Erythrocyte sedimentation rate and C-reactive protein level are often the first investigations ordered; however, the results of these tests can be normal in up to $24 \%$ of patients with giant cell arteritis that is later confirmed with biopsy. ${ }^{3}$ In our patient, even after his symptoms progressed, his erythrocyte sedimentation rate was only $30 \mathrm{~mm} / \mathrm{h}$. If giant cell arteritis is suspected, the diagnosis should be pursued despite an erythrocyte sedimentation rate that is considered to be normal by even the most sensitive criteria.

Our patient's CT angiogram showed circumferential thickening of the vessel walls over long extracranial segments of the vertebral arteries. These findings were atypical for atherosclerotic disease because of the circumferential and extensive enlargement of the arterial wall. In addition, the changes were only present in the vertebral arteries and not in the anterior and intracranial circulation. Dissection of the vertebral arteries is indicated by focal thickening of the vessel wall, which can be seen on a CT angiogram. ${ }^{7}$ Typically, these findings are more localized to the suboccipital portion. While caring for our patient, we were not aware of previous reports of increased thickness of the vertebral arteries appearing in ultrasound and magnetic resonance angiogram images of patients with giant cell arteritis. ${ }^{89}$ For our patient, the magnetic resonance angiogram was pivotal in alerting us to the possibility of vasculitis because it showed a rapid progression in the severity and distribution of the stenosis.

The vertebral artery is commonly affected in giant cell arteritis. In patients with giant cell arteritis, $50 \%-75 \%$ of strokes occur in the vertebrobasilar circulation (compared with $15 \%-20 \%$ of strokes in patients without giant cell arteritis). ${ }^{6,10}$ Our patient developed bilateral occlusion of the vertebral arteries, which was confirmed by cerebral angiography. This occurs in only $0.1 \%-0.2 \%$ of patients with cerebrovascular disease. ${ }^{11}$ In a review of the literature, $8(6.8 \%)$ of 118 cases of nontraumatic bilateral occlusion of the vertebral arteries were due to giant cell arteritis. ${ }^{11}$ The absence of occlusions of the intradural portion of the vertebral arteries was a feature that distinguished giant cell arteritis from atherosclerotic

Table 1: Initial manifestation and clinical findings in 100 patients with temporal arteritis

\begin{tabular}{|c|c|c|c|}
\hline \multirow[b]{2}{*}{ Feature } & \multicolumn{2}{|c|}{ No. of patients } & \multirow[b]{2}{*}{ Description } \\
\hline & $\begin{array}{c}\text { At } \\
\text { presentation }\end{array}$ & $\begin{array}{l}\text { Finding at } \\
\text { diagnosis }\end{array}$ & \\
\hline Headache & 32 & 68 & Continuous generalized or temporal pain ${ }^{3}$ \\
\hline Polymyalgia rheumatica & 25 & 39 & $\begin{array}{l}\text { Pain in the neck, shoulder girdle or pelvic } \\
\text { girdle; prolonged muscle stiffness upon } \\
\text { waking }^{3}\end{array}$ \\
\hline Fever & 15 & 42 & Elevated body temperature (e.g., $\left.39^{\circ} \mathrm{C}\right)^{3}$ \\
\hline $\begin{array}{l}\text { Visual symptoms } \\
\text { without loss of vision }\end{array}$ & 7 & 30 & $\begin{array}{l}\text { Amaurosis fugax (precedes permanent loss of } \\
\text { vision in } 44 \% \text { of patients), }{ }^{3} \text { diplopia or eye } \\
\text { pain }^{4}\end{array}$ \\
\hline $\begin{array}{l}\text { Weakness, malaise or } \\
\text { fatigue }\end{array}$ & 5 & 40 & May be the only presenting symptoms ${ }^{4}$ \\
\hline Tenderness over arteries & 5 & 27 & $\begin{array}{l}\text { The frontal and parietal branches of the } \\
\text { superficial temporal arteries may be } \\
\text { thickened, nodular, erythematous and tender }\end{array}$ \\
\hline Myalgia & 4 & 30 & \\
\hline Weight loss or anorexia & 2 & 50 & May be mistaken for malignant disease ${ }^{4}$ \\
\hline Claudication of the jaw & 2 & 45 & $\begin{array}{l}\text { Pain while chewing due to ischemia of the } \\
\text { muscles of the jaw }{ }^{3}\end{array}$ \\
\hline Permanent loss of vision & 1 & 14 & $\begin{array}{l}\text { Anterior ischemic optic neuropathy due to } \\
\text { occlusion of the posterior ciliary arteries }{ }^{3}\end{array}$ \\
\hline $\begin{array}{l}\text { Claudication of the } \\
\text { tongue }\end{array}$ & 1 & 6 & $\begin{array}{l}\text { Pain due to ischemia of the muscles } \\
\text { controlling the tongue }\end{array}$ \\
\hline
\end{tabular}




\section{Box 1: The American College of Rheumatology diagnostic criteria} for giant cell arteritis ${ }^{5}$

Patients should meet three of the following:

- Age $\geq 50$ years

- New onset of localized headache

- Tenderness or decreased pulse in the temporal artery

- Erythrocyte sedimentation rate $\geq 50 \mathrm{~mm} / \mathrm{h}$

- A positive biopsy of the temporal artery showing mononuclear cell infiltrates or a granulomatous process with multinucleate giant cells

\section{Box 2: Red flags for the diagnosis of giant cell arteritis in patients} presenting with stroke

- Headache or tenderness of the temporal artery

- Constitutional symptoms such as fever, malaise or weight loss

- Bilateral occlusions or severe stenoses of the vertebral arteries

- Imaging studies showing involvement of only the extracranial vessels and not the intracranial segments
$93 \%$ of 30 patients with giant cell arteritis. ${ }^{12}$ Contrast-enhanced MRI of the superficial cranial arteries may be an adjunct to other diagnostic studies. In 21 patients being examined for giant cell arteritis, contrast-enhanced MRI showed a diagnostic sensitivity of $88.9 \%$ and a specificity of 91.7\% when compared with the American College of Rheumatology criteria; the diagnostic sensitivity was $100 \%$ and the specificity $80 \%$ when compared with biopsy of the temporal artery. ${ }^{13}$

\section{Management}

When giant cell arteritis is suspected, clinical guidelines recommend rapid initiation of corticosteroid treatment and biopsy of the temporal artery as soon as possible. ${ }^{14}$ Biopsy results remain positive for at least two weeks after the start of steroid therapy. ${ }^{15}$ The recommended starting dose of prednisone depends on the severity of symptoms. A dose of $40-60 \mathrm{mg} / \mathrm{d}$ is usually recommended until the symptoms resolve and laboratory tests show normal results (at least 3-4 weeks), at which point the dose is tapered as follows: a reduction in dose by $10 \mathrm{mg} / \mathrm{d}$ every two weeks until a dose of $20 \mathrm{mg} / \mathrm{d}$ is reached, a further reduction of $2.5 \mathrm{mg} / \mathrm{d}$ every two to four weeks until a dose of $10 \mathrm{mg} / \mathrm{d}$ is reached, and a final reduction of $1 \mathrm{mg} / \mathrm{d}$ every $1-2$ months until the patient is no longer receiving any of the medication. ${ }^{14,15}$ If vision is threatened, 500$1000 \mathrm{mg} / \mathrm{d}$ of intravenous methylprednisolone for three days before starting the oral prednisone regimen is more likely to improve vision than oral prednisone alone. ${ }^{14,15}$ Antiplatelet treatment is also recommended if there is no contraindication, because it has been reported to reduce the risk of loss of vision and stroke in patients with giant cell arteritis. ${ }^{14,16,17}$ Unfortunately, our patient's condition continued to deteriorate despite receiving intravenous heparin and high doses of steroids.

This report shows just how vigilant clinicians must be in considering the possibility of giant cell arteritis. The early recognition of symptoms and rapid initiation of treatment are critical and often lie in the hands of the family physician. The management of this complicated condition requires the involvement of various consultants, including rheumatologists, neurologists and ophthalmologists. first side is normal; however, $10 \%$ of biopsies in patients with giant cell arteritis remain negative with this approach. ${ }^{3}$ Although rare, the complications related to undergoing a biopsy may include injury to the frontal branch of the facial nerve, infection, bleeding and skin necrosis. ${ }^{2}$

Noninvasive imaging studies are emerging as important diagnostic tools. An ultrasound study showed abnormalities in the temporal artery in

\section{References}

1. Miller A, Green M, Robinson D. Simple rule for calculating normal erythrocyte sedimentation rate. BMJ 1983;286:266.

2. Melson MR, Weyand CM, Newman NJ, et al. The diagnosis of giant cell arteritis. Rev Neurol Dis 2007;4:128-42.

3. Cantini F, Niccoli L, Nanninni C, et al. Diagnosis and treatment of giant cell arteritis. Drugs Aging 2008;25:281-97.

4. Moltyaner Y, Tenenbaum J. Temporal arteritis: a review and case history. J Fam Pract 1996;43:294-300. 
5. Hunder GG, Bloch DA, Michel BA, et al. The American College of Rheumatology 1990 criteria for the classification of giant cell arteritis. Arthritis Rheum 1990;33:1122-8.

6. Wiszniewska M. Giant cell arteritis as a cause of first-ever stroke. Cerebrovasc Dis 2007;24:226-30.

7. Lum C. Vertebral artery dissection with a normal appearing lumen at multisection CT angiography: the importance of identifying wall hematoma. AJNR Am J Neuroradiol 2009;30:787-92.

8. Pfadenhauer K, Esser M. Vertebrobasilar ischemia and structural abnormalities of the vertebral arteries in active temporal arteritis and polymyalgia rheumatica - an ultrasonographic case-control study. J Rheumatol 2005;32:2356-60.

9. Geiger J. 3-T MRI detects inflammatory stenosis of the vertebral artery in giant cell arteritis. Clin Rheumatol 2008;27:663-6.

10. Gonzalez-Gay MA, Pineiro A, Gomez-Gigirey A, et al. Influence of traditional risk factors of atherosclerosis in the development of severe ischemic complications in giant cell arteritis. Medicine 2004;83:342-7.

11. Ruegg S, Engelter S. Bilateral vertebral artery occlusion resulting from giant cell arteritis: report of 3 cases and review of the literature. Medicine (Baltimore) 2003;82:1-12.

12. Schmidt WA, Kraft HE, Vorpahl K, et al. Color duplex ultrasonography in the diagnosis of temporal arteritis. $N$ Engl J Med 1997;337:1336-42.

13. Bley TA, Weiben $\mathrm{O}$, Uhl M, et al. Assessment of the cranial involvement pattern of giant cell arteritis with $3 \mathrm{~T}$ magnetic resonance imaging. Arthritis Rheum 2005;52:2470-7.

14. Dasgupta B, Borg FA, Hassan N, et al., BSR and BHPR guidelines for management of giant cell arteritis. Rheumatology (Oxford) 2010;49:1594-7.

15. Fraser JA, Weyand CM, Newman NJ, et al. The treatment of giant cell arteritis. Rev Neurol Dis 2008;5:140-52.

16. Lee MS, Smith SD, Galor A, et al. Antiplatelet and anticoagu- lant therapy in patients with giant cell arteritis. Arthritis Rheum 2006;54:3306-9.

17. Warrington KJ, Matteson EL. Management guidelines and outcome measures in giant cell arteritis. Clin Exp Rheumatol 2007; 25(6Suppl 47):137-41.

Competing interests: Mukul Sharma is a consultant for the Canadian Agency for Drugs and Technologies in Health and Talecris Biotherapeutics; he is employed with the Canadian Stroke Network; he has received grants from the Heart and Stroke Foundation of Canada and the Canadian Institutes of Health Research; and he has received payment for lectures from Sanofi - Bristol-Myers Squibb, Boehringer-Ingelheim, Pfizer and Merck. Cheemun Lum has received a speaker fee from Siemens. No other competing interests were declared.

Affiliations: From the Division of Neurology (Zwicker, Sharma), The Ottawa Hospital, Ottawa, Ont.; The Ottawa Hospital Research Institute (Sharma), Ottawa, Ont.; the Division of Neurology and the Department of Ophthalmology (Atkins), Royal University Hospital, Saskatoon, Sask.; and the Department of Radiology (Lum), Ottawa Hospital, Ottawa, Ont.

Contributors: Jocelyn Zwicker, Cheemun Lum and Mukul Sharma were directly involved in the patient's treatment and acquired the data for the article. Jocelyn Zwicker also researched and drafted the article, Mukul Sharma contributed substantially to its design, and Edward Atkins and Cheemun Lum revised an earlier draft. All of the authors approved the final version submitted for publication. 